Вісник ЛНУ імені Тараса Шевченка № 6 (329), Ч. I, 2019

UDC 378.091:316.62

DOI: 10.12958/2227-2844-2019-6(329)-1-128-134

Streltsova Victoria,

Candidate of Pedagogical Sciences

ekaterinadashkova25@gmail.com

https://orcid.org/0000-0002-8218-2076

Karlyuk Sergey,

Senior Lecturer of the Department of Foreign Languages

of Faculty for International Education of National Technical University

«Kharkiv Polytechnic Institute», Kharkiv, Ukraine.

sergejkarlyuk70@gmail.com

https://orcid.org/0000-0002-5435-4010

\title{
DIRECTIONS IN SOCIO-PEDAGOGIC ACTIVITIES CONCERNING A RAISE IN EFFICIENCY OF FOREIGN STUDENTS' SOCIALIZATION PROCESS IN THE ASPECT OF GLOBALIZATION PROCESSES IN HIGHER EDUCATION
}

Defining the problem. In the modern world, learning cannot be restricted by national priorities only. By attaining global traits, education ensures conditions for stable development of a person, a society, and a state. International cooperation is a powerful lever of the world higher education's development, and is to perform an important role in ascertaining peace, mutual understanding and tolerance, in forming of mutual trust between peoples and countries. In current conditions of social life development in Ukraine, when higher education institutions have gained considerable autonomy, the role of international activity considerably increases, and training of foreign citizens becomes an important factor in strengthening authority and prestige of a higher education institution, that stipulates the topicality of educational migration in socio-cultural environment of Ukraine. An important goal of Ukraine's higher education institutions is entering the international market of education services, and one of the ways of solving this task can be the success in internationalstudents' socialization.

Recent research and publications analysis. Educational migration within the context of development of Ukraine's education system was studied by O. Gorchakova， A. Grynenko， V. Zhuravsky, O. Nitenko, Ya. Romashova, $\mathrm{O}$. Yastremska, et al. In recent years, various aspects of training international students at higher education institutions were studied by the following Ukrainian and foreign researchers: I Al-Shabul, L. Aseikina, N. Bulgakova, L. Vasetska, N. Vasylenko, T. Dementieva, Ye. Lin, O. Yevdokymova, I. Zozulya, V. Kolomiyets, V. Kostomarov, I. Kushnir, Lin Hai, L. Mazitova, N. Mayatska, T. Merkulova, V. Nikolayenko, O. Palka, O. Rezvan, 


\section{Вісник ЛНУ імені Тараса Шевченка № 6 (329), Ч. I, 2019}

L. Rybachenko, Ye. Stepanov, N. Tereschenko, N. Ushakova, A. Chistyakova, TzianYuetsi, Zin Nan, O. Schukin, et al. The issues of social, sociopsychological, and socio-cultural adaptingof foreign students to a foreign socio-cultural environment were viewed by K. Burakova, L. Butenko, I. Grebennikova, M. Ivanova. Despite numerous research of various aspects of educational migration, insufficient attention is paid in modern science literature to studying the directions of socio-pedagogic activities concerning the raise in efficiency of educational migrants' socialization within the context of current socio-cultural situation.

The goal of the article is to consider the directions and technologic support of the international students' socialization process in the aspect of globalization processes within the sphere of higher education.

The results of theoretic research. Providing educational services is becoming one the main export branches for countries that position themselves as leaders in the international education services market. According to the data published by the UNESCO Statistics Institute and Economic Cooperation and Development Organization, more than 4.5 million of internationalstudents are currently involved in the international education services market, and the annual growth of this market is currently observed at the level of about $6.7 \%$. The leaders in internationalstudents' training are the EU (38\% market share) and the North America countries (23\% market share). The main regions "supplying" students abroad are Asian countries (about 52\%), the highest index belonging to China (nearly 20\%). According to the data of the mentioned Institute, the main factors influencing the selection of the country to study in, are the language of teaching, training program's quality, cost of education and living, the target country's immigration policies (the possibility of employment following the obtaining of an education) (http://intered.com.ua/web-resource). The presented statistical data attest tothe fact that currently Ukraine despite the complicated economic and political situation in the country has retained its attractiveness for foreign students. An urgent task at present is to maintain and improve this situation through a system of purposeful measures within the sphere of education quality and that of living standards, as well as to improve the educational migration process management, that stipulates the need in growing attention to socialization of international students, which is an important factor in the efficiency of the training process and takes place in a foreign pedagogic system from a student's perspective.

The greatest interest in the problems of foreign students' adapting and socialization arose in mid-50s of last century, which was connected with the post-war boom in exchange of students and specialists, as well as with migration processes. The need in studying these issues has grown considerably in recent years, which is connected with the need in education systems' transformation and is stipulated by countries' needs in removing barriers impeding free movement and communication in the world environment. Since the social adaptation process is a complex and multi-faceted object in the dimension of a 


\section{Вісник ЛНУ імені Тараса Шевченка № 6 (329), Ч. I, 2019}

higher education institution's cultural-and-education environment being under the impact of numerous factors, to ensure the efficiency of this process it is primarily necessary to pay attention to socially controlled foreign students' socialization, i.e. to social upbringing in an institution's education-and-cultural environment. A. Ryzhanova determines social upbringing as "a process of purposefully created conditions for development of social subjects' sociality in every sphere of a society" (Ryzhanova, 2005, p.14). And she interprets sociality as "a goal of social upbringing, a hierarchy of social values, social qualities, and social behavior leading to a socio-educational result - a manifestation of individual, positively-creative attitude to social life, in particular to its family, ethnic, religious, global aspects, etc." (Ryzhanova, 2005, p.14). Socio-pedagogic activity is viewed by the researcher as "a scientifically substantiated, corresponding to the culture regulation of social upbringing in every sphere with the aim of non-compulsory attaining and development of sociality in social subjects (Ryzhanova, 2005, p.14). To raise international students' sociality level it is necessary within socio-pedagogic activity to practice involving them into an active social activity on the premises of the "social probes" technology along with socio-pedagogic guidance of international students.

Involving students into active social activities supposes intensive interaction between the two subjects of social creativity - a student's personality and various social institutions, both subjects, notably, being in the state of permanent transformation, development, and mutual influencing one another. The process of their interaction evolves in a kind of an "adaptation space", wherein pedagogues are able to model various social situations, turning it into the so-called "social probes field".

It is proved that a social probe is a peculiar pedagogic mechanism that places a student into unfamiliar social conditions, requiring working out a new behavioral model, causing a personality's adapting mechanism to be activated on physiological, psychic, and social levels.

An important socio-pedagogic condition that ensures efficacy of the process of international students' socialization into conditions of a higher education institution's cultural-and-education environment is socio-pedagogic support of this process which is defined as an assistance to a student in the process of social adaptation that is based on empathic understanding of his/her problems, free communication and creative interaction; as a special kind of higher education pedagogues, tutors, all personnel responsible for educative work with students aimed at removing psychologic stress in the course of a student's social formation at a higher education institution; as a peculiar kind of pedagogic support oriented at a high level of a student's freedom and independence.

Under the pedagogic support of international students' socialization processwe mean the assistance, which is based on empathic interaction and communication as a special kind of activity of a higher education institution pedagogues and tutors, of all personnel responsible for educative work with students aimed at removing psychologic stress in the course of a student's being included into a foreign culture and their forming intercultural 


\section{Вісник ЛНУ імені Тараса Шевченка № 6 (329), Ч. І, 2019}

competence, namely a positive attitude to various ethnic cultures.

As additional characteristics which make it possible to describe the nuances of pedagogic support in more detail we will highlight the following:

- pedagogic support is a process that is conducted professionally and is targeted at providing preventive assistance to foreign students;

- the sphere of pedagogic support also includes, apart from purely adaptive tasks, the issues of multiculturalism policy;

- provision of a possibility to maintain an intercultural polylogue based on interaction, interpenetrating, and inter-complementation;

- establishing strong intercultural and interpersonal communication between representatives of different cultures;

- including emotional component into the contents of pedagogic support determines the presence of emotional environment at a higher education institution, which we interpret as a certain field of relationships wherein a personality realizes itself by manifesting certain emotions or interacting with another person.

It is pedagogic support that in certain cases attains the traits of preventive pedagogic support. This peculiarity is determined by its being directed at a student's personality diagnostics that enable a pedagogue to project the nearest zone of his/her actual socialization needs. The essence of such a support lies in providing international students with information they will need soon.

The content foundation of the technologies ensuring success of the adaptation process is made up of various forms and directions in pedagogic activities. Among the most successful ones we may note the following: special trainings, individual consultations, language courses, country study excursions, social practices, psychologic support, organization of informal communication between foreign and Ukrainian students, and so on. The use of learning videos containing information as to Ukrainians' ethnic culture can not only facilitate internationalstudents' adaptation processes, but also make a considerable positive impact on raising quality of future specialists' professional training for foreign countries. The combination of formal methods of teaching (classroom work, presenting theoretic material) with informal ones (use of a recently seen video-material from social networks, chats, web conferences communication etc. for discussion) determines intensity of education and adaptation process.

Finally, to solve the problems of international students' adaptation it is necessary to create socio-pedagogic conditions that will facilitate this process.Such socio-pedagogic conditions are: creating a favorable sociopedagogic environment, the unity of training and education process intended for international students, cooperation of a higher education institution with other social institutions concerning the issue of foreign students' staying in Ukraine. Usually, there is a special structural unit responsible for international student's staying within the education-and-cultural environment of a higher education institution. This may be the foreign students' training department, the international education and cooperation center, the foreign citizens' 


\section{Вісник ЛНУ імені Тараса Шевченка № 6 (329), Ч. I, 2019}

training center, the international department, etc. This structural unit maintains coordination of international students' learning activities, evaluates the quality of training and methodological support of the training process for international students, their registration for staying in Ukraine, as well as educational work.

Conclusions. The processes of international education migration call for improvement of international students' training system, efficiency of which is determined, to a large extent, by succeeding in international students' socialization, and which primarily takes place within the education-and-cultural environment of a higher education institution. For ensuring efficiency of this process in terms of current socio-cultural situation, it is, first of all, necessary to pay attention to socially controlled internationalstudents' socialization which can be accomplished through involving them into active social interaction on the grounds of socio-pedagogic technology of "social probes" along with socio-pedagogic support of international students. Thus, the goal of socio-pedagogic activity concerning socialization of international students within the aspect of globalization processes in the sphere of higher education is transforming the international students into a subject of socialization, which is a perspective of our further research.

\section{Список використаної літератури}

1. Актуальні статистично-аналітичні показники надання освітніх послуг іноземцям. Офіційний сайт Українського державного центру міжнародної освіти Міністерства освіти і науки України [Електронний pecypc]. Режим доступу: http://intered.com.ua/. 2. Рижанова А. О. Розвиток соціальної педагогіки в соціокультурному контексті: автореф. дис. на здобуття наукового ступеня доктора пед. наук: спец. 13.00.05 «Соціальна педагогіка». Луганськ, 2005. 44 с.

\section{References}

1. Aktualni statystychno-analitychni pokaznyky nadannia osvitnikh posluh inozemtsiam. Ofitsiinyi sait Ukrainskoho derzhavnoho tsentru mizhnarodnoi osvity Ministerstva osvity i nauky Ukrainy [Current statistical and analytical indicators of providing educational services to foreigners. Official site of the Ukrainian State Center for International Education of the Ministry of Education and Science of Ukraine]. Retrieved from http://intered.com.ua/ [in Ukrainian]. 2. Ryzhanova, A. O. (2005). Rozvytok sotsialnoi pedahohiky v sotsiokulturnomu konteksti [Development of social pedagogy in socio-cultural context]. Extended abstract of Doctor's thesis. Luhansk [in Ukrainian].

Стрельцова В. Ю., Карлюк С. В. Напрями соціальнопедагогічної діяльності щодо підвищення ефективності процесу соціалізації іноземних студентів в аспекті глобалізаційних процесів у сфері вищої освіти

У статті зроблена спроба обгрунтування необхідності пошуку ефективних соціально-педагогічних технологій, орієнтованих на 


\section{Вісник ЛНУ імені Тараса Шевченка № 6 (329), Ч. І, 2019}

підвищення ефективності соціалізації студентів-іноземців. Автори представляють напрями соціально-педагогическої діяльності, які забезпечують ефективне включення студентів-іноземців у нове соціальнокультурне середовище. Запропоновано соціально-педагогічну технологію «соціальних проб», сукупність відповідних форм та методів роботи (дискусії, метод творчих соціальних проектів, спеціальні тренінги, ділові імітаційні ігри, соціальні практики, ситуації соціальних проб тощо).

Доведено, що соціальна проба - це особливий педагогічний механізм, який ставить студента в незнайомі для нього соціальні умови, вимагає від нього вироблення нової моделі поведінки, примушує активізуватися адаптаційні механізми особистості на фізіологічному, психічному й соціальному рівнях.

Важливою соціально-педагогічною умовою, що забезпечує ефективність процесу соціалізації іноземних, $є$ соціально-педагогічний супровід цього процесу, який визначено як допомогу студенту в процесі соціальної адаптації, що грунтується на емпатійному розумінні його проблем, вільному спілкуванні й творчій взаємодії; як особливу галузь діяльності педагогів 3ВО, кураторів груп, усіх відповідальних за виховну роботу зі студентами, спрямовану на зняття психологічного напруження в ході соціального становлення у 3ВО; як особливий вид педагогічної підтримки, орієнтований на високий ступінь свободи й автономії студента.

Ключові слова: міжнародна освітня міграція, педагогічний супровід, соціально-педагогічна технологія «соціальних проб», соціалізація студентів-іноземців.

Стрельцова В. Ю., Карлюк С. В. Направления социальнопедагогической деятельности, повышающие эффективность процесса социализации иностранных студентов в аспекте глобализационных процессов в сфере высшего образования

В статье предпринята попытка обоснования необходимости поиска эффективных социально-педагогических технологий, ориентированных на повышении эффективности социализации студентов-иностранцев. Авторы представляют направления социально-педагогической деятельности, которые могут обеспечивать эффективное вхождение студентов-иностранцев в новую социокультурную среду. Предложена социально-педагогическая технология «социальных проб», совокупность соответствующих форм и методов работы (дискуссии, метод реализации разнообразных социальных проектов, специальные тренинги, деловые имитационные игры, социальные практики).

Доказано, что социальная проба - это особый педагогический механизм, который ставит студента в незнакомые для него социокультурные условия, требует от него выработки новой модели поведения, заставляет активизироваться адаптационные механизмы личности на физиологическом, психическом, языковом, социальном уровнях.

Важным социально-педагогическим условием, обеспечивающим 


\section{Вісник ЛНУ імені Тараса Шевченка № 6 (329), Ч. І, 2019}

эффективность процесса социализации иностранных студентов является социально-педагогическое сопровождение этого процесса, который определен как помощь студенту в процессеи социокультурной адаптации, основанный на эмпатийном понимании его проблем, свободном общении и взаимодействии как особую область деятельности педагогов вузов, кураторов групп и всех ответственных за работу со студентами-иностранцами, направленную на снятие психологического напряжения в ходе социально-культурного становления, как особый вид педагогической поддержки, ориентированной на высокую степень свободы и автономии студента.

Ключевые слова: международная образовательная миграция, социально-педагогическая технология «социальных проб», педагогическое сопровождение, социализация студентов-иностранцев.

\section{Streltsova V., Karlyuk S. Directions in Socio-Pedagogic Activities Concerning a Raise in Efficiency of Foreign Students' Socialization Process in the Aspect of Globalization Processes in Higher Education}

The article represents an attempt to substantiate the need in a search for efficient socio-pedagogic technologies directed at improving efficiency of international students' socialization. The authors present directions of sociopedagogic activities that ensure efficient involvement of international students into a new socio-cultural environment. There are offered the socio-pedagogic technology of "social probes", a complex of corresponding forms and methods of work (discussions, the creative social projects method, special trainings, simulation games, social practices, social probes situations, etc.).

An important socio-pedagogic condition that ensures efficacy of the process of international students' socialization into conditions of a higher education institution's cultural-and-education environment is socio-pedagogic support of this process which is defined as an assistance to a student in the process of social adaptation that is based on empathic understanding of his/her problems, free communication and creative interaction; as a special kind of higher education pedagogues, tutors, all personnel responsible for educative work with students aimed at removing psychologic stress in the course of a student's social formation at a higher education institution; as a peculiar kind of pedagogic support oriented at a high level of a student's freedom and independence.

Thus, the goal of socio-pedagogic activity concerning socialization of international students within the aspect of globalization processes in the sphere of higher education is transforming the international students into a subject of socialization, which is a perspective of our further research.

Key words: international education migration, pedagogic support, sociopedagogic technology of "social probes", international students' socialization.

Стаття надійшла до редакції 18.09.2019 p.

Прийнято до друку 25.10.2019 р.

Рецензент - д.п.н., проф. Гришак С. М. 